\title{
PERTOLONGAN PERTAMA KELUARGA PADA LUKA BAKAR SEBELUM DIBAWA KE IGD RSUD NGUDI WALUYO WLINGI
}

\author{
Dewi Rachmawati ${ }^{1}$, Risky Gusher Saputro ${ }^{2}$, Agus Khoirul Anam ${ }^{3}$ \\ $1 \&$ 3, Jurusan Keperawatan, Politeknik Kesehatan Kemenkes Malang \\ 2, Mahasiswa Prodi Keperawatan Blitar, Politeknik Kesehatan Kemenkes Malang \\ *Email: rachmawatidewi13@yahoo.com
}

\begin{abstract}
Abstrak
Luka bakar merupakan salah satu kecelakaan di rumah tangga dengan proporsi yang tertinggi dan memerlukan perawatan yang sangat kompleks. Tujuan dari studi kasus ini adalah menggambarkan pertolongan pertama keluarga pada kejadian luka bakar. Studi kasus ini menggunakan metode deskriptif. Subjek penelitian adalah anggota keluarga yang pernah memberikan pertolongan pertama luka bakar sebanyak 4 partisipan. Pengumpulan data ini menggunakan wawancara dan observasi keterampilan. Hasil penelitian menunjukkan pertolongan pertama pada kejadian luka bakar ringan, meliputi: memastikan 3A, menghilangkan sumber luka bakar, mendinginkan luka bakar dengan air mengalir, menutup luka dengan kasa, membawa ke rumah sakit. Luka bakar sedang, meliputi: menjauhkan korban dari tempat kejadian, mengolesi luka dengan odol, mendinginkan luka dengan kipas, segera membawa ke rumah sakit. Luka bakar berat, meliputi: memastikan aman diri dan pasien, berteriak meminta bantuan, menghentikan luka bakar dengan menggunakan handuk basah, memanggil nama korban karena korban tidak sadar, melepaskan pakaian yang menutupi luka, mendinginkan luka bakar dengan kipas, melindungi area luka bakar dengan kain basah, segera membawa ke rumah sakit. Dapat disimpulkan bahwa tindakan pertolongan pertama yang dilakukan berbeda, tergantung jenis, penyebab, luas, pengetahuan, dan informasi tentang pertolongan pertama luka bakar. Maka dari itu diperlukan pendidikan tentang pertolongan pertama luka bakar terutama pada masyarakat.
\end{abstract}

Kata kunci: luka bakar, keluarga \& pertolongan pertama.

\begin{abstract}
Family First Aid for Burns Before Being Taken to the Emergency Room at Ngudi Waluyo Wlingi Hospital . Burns are one of the highest numbers of household accidents and require very complex treatment. The purpose of this case study is to describe the family's first aid in the event of a burn. This case study uses a descriptive method. Subjects were family members who had given first aid burns to as many as 4 participants. This data collection uses interviews and observation skills. The results showed first aid in the incidence of minor burns, including: ensuring 3A, removing the source of burns, cooling the burn with running water, closing the wound with gauze, bringing it to the hospital. Moderate burns, including: keep the victim away from the scene, smear the wound with toothpaste, cool the wound with a fan, immediately bring it to the hospital. Heavy burns, including ensuring self and patient safety, shouting for help, stopping burns using a wet towel, calling the victim's name because the victim is unconscious, removing clothes that cover the wound, cooling the burn with the fan, protecting the burn area with cloth wet, immediately bring to the hospital. It can be concluded that doing the first aid is different, depending on the type, cause, extent, knowledge, and information about first aid burns. Therefore we need education about first aid burns, especially in the community.
\end{abstract}

Keywords: burns, family \& first aid. 


\section{Pendahuluan}

Kecelakan di rumah tangga menjadi kecelakaan dengan proporsi tertinggi tempat kejadian cedera pada tahun 2018, dengan persentase 44,7\% (Badan Penelitian \& Pengembangan Kesehatan Kemenkes RI, 2019). Salah satu kecelakaan yang terjadi di rumah adalah luka bakar, maka dari itu pertolongan pertama luka bakar sangat penting (pre hospital). Penanganan dan perawatan luka bakar sampai saat ini masih memerlukan perawatan yang kompleks dan masih merupakan tantangan yang harus diperbaiki dari waktu ke waktu, karena sampai saat ini angka morbiditas dan mortalitas yang masih tinggi (Noer $d k k, 2018$ ). Banyak mitos yang salah di masyarakat dalam melakukan pertolongan pertama pada luka bakar, misalnya mengoleskan odol, margarin atau kecap pada kulit yang terkena luka bakar, masih banyak masyarakat yang percaya, kalau luka bakar di rumah khususnya, kalau diguyur air akan semakin parah. Pertolongan pertama sangat dibutuhkan bagi keluarga, Pertolongan pertama ini diperlukan antara lain untuk mencegah efek lanjut yang tidak diinginkan dan mempertahankan kondisi jika ternyata perlu dilakukan rujukan menuju pusat pengobatan (Herawati \& Argarini, 2015). Pertolongan pertama yang harus dilakukan pertama kali adalah membebaskan tubuh penderita dari bahan penyebab. Daerah yang terbakar cukup direndam/disiram dengan air dingin (jangan air es) karena akan menambah sakit. Luka bakar yang luas perlu segera mendapatkan tambahan cairan untuk mencegah dehidrasi, jika wilayah terbakar $>10 \%$ penderita harus dirawat di RS (Susilowati, 2015).

Dari hasil studi pendahuluan di IGD Rumah Sakit Ngudi Waluyo Wlingi didapatkan data bahwa kejadian luka bakar yang di rawat di IGD Ngudi Waluyo Wlingi selama tahun 2018 terdapat 42 kasus, sebagian besar luka bakar diakibatkan oleh tersiram air panas, minyak goreng dan api. Salah satu wilayah terbanyak dari kasus luka bakar yang dibawa ke rumah sakit Ngudi Waluyo Wlingi adalah wilayah Kecamatan Selopuro Kabupaten Blitar.

Untuk itu sangat penting memberikan pertolongan pertama pada saat terjadi luka bakar di rumah, oleh sebab itu berdasarkan latar belakang diatas akan dilakukan penelitian tentang pertolongan pertama keluarga pada luka bakar sebelum dibawa ke IGD RSUD Ngudi Waluyo Wlingi.

\section{Metode}

Penelitian ini menggunakan metode studi pendekatan deskriptif. Tempat penelitian di wilayah kerja Puskesmas Selopuro. Adapun 
subjek dalam studi kasus ini adalah Anggota yang pernah memberikan pertolongan pertama pada luka bakar sebanyak 4 partisipan, dengan kriteria inklusi: 1). Anggota keluarga yang pernah memberikan pertolongan pertama luka bakar sebelum dibawa ke IGD, 2). Anggota keluarga yang menolong korban luka bakar ringan/sedang/berat yang disebabkan oleh api/air panas, 3). Tinggal satu rumah dengan korban luka bakar saat kejadian.

Metode pengumpulan data dengan wawancara dan observasi untuk penilaian keterampilan partisipan. Untuk langkahlangkah pengumpulan data diawali dengan 1).Mengidentifikasi pasien yang mengalami luka bakar yang dirujuk ke IGD RSUD Waluyo Wlingi oleh Puskesmas Selopuro, 2).Mengidentifikasi luka bakar yang diderita apakah ringan/sedang/berat, 3).Mengidentifikasi penyebab luka bakar terutama yang disebabkan oleh termal/panas (api/air panas), 4). Mengidentifikasi alamat rumah pasien, 5). Meminta persetujuan responden, 6). Melakukan kontrak waktu pelaksanaan penelitian, 7). Melakukan wawancara kepada partisipan tentang cara melakukan pertolongan pertama luka bakar, 8). Melakukan observasi keterampilan partisipan dalam memperagakan cara pertolongan pertama luka bakar, 9).
Melakukan terminasi penelitian sudah selesai dilakukan, 10). Melakukan analisa data.

Teknik analisis data yang dilakukan adalah menarasikan hasil wawancara masingmasing partisipan dalam memberikan pertolongan pertama luka bakar, untuk observasi hasil keterampilan dilakukan analisis deskriptif dengan menghitung nilai keterampilan partisipan dengan rumus (Arikunto, 2010):

$P=\frac{F}{N} X 100 \%$

Keterangan:

$\mathrm{P}=$ Prosentase

$\mathrm{F}=$ Jumlah jawaban yang benar

$\mathrm{N}=$ Jumlah Soal

Kemudian nilai keterampilan yang diperoleh dikategorikan sebagai berikut: Nilai $76-100 \%$ dalam kategori baik, nilai $56-75 \%$ dalam kategori cukup dan nilai 40-55\% dalam kategori kurang. Setelah data di kategorikan kemudian disajikan dalam bentuk tabel dan narasi. Pertimbangan etik yang diterapkan adalah autonomy (memberikan kebebasan kepada partisipan bersedia atau tidak bersedia menjadi subjek penelitian dengan menandatangani atau tidak menandatangani informed consent), anonymity (tidak mencantumkan nama partisipan pada lembar observasi atau wawancara tetapi hanya mencantumkan inisial saja), keadilan 
(penerapannya dalam bentuk semua partisipan mendapatkan perlakukan yang sama baik sebelum, selama maupun sesudah penelitian berlangsung), beneficence (manfaat) diterapkan dengan memberikan informasi tentang pertolongan pertama yang benar pada partisipan setelah selesai melakukan wawancara dan observasi keterampilan dan non maleficience (kerugian) penerapan prinsip etik ini adalah melakukan kontrak waktu terlebih dahulu kepada partisipan dan apabila partisipan merasa lelah selama penelitian berlangsung maka partisipan dapat berhenti dalam keikutsertaan sebagai partisipan.

\section{Hasil}

Berdasarkan hasil penelitian dengan melakukan observasi keterampilan pada 4 partisipan maka keterampilan masing-masing partisipan dalam memberikan pertolongan pertama luka bakar ditunjukkan pada grafik dibawah ini:

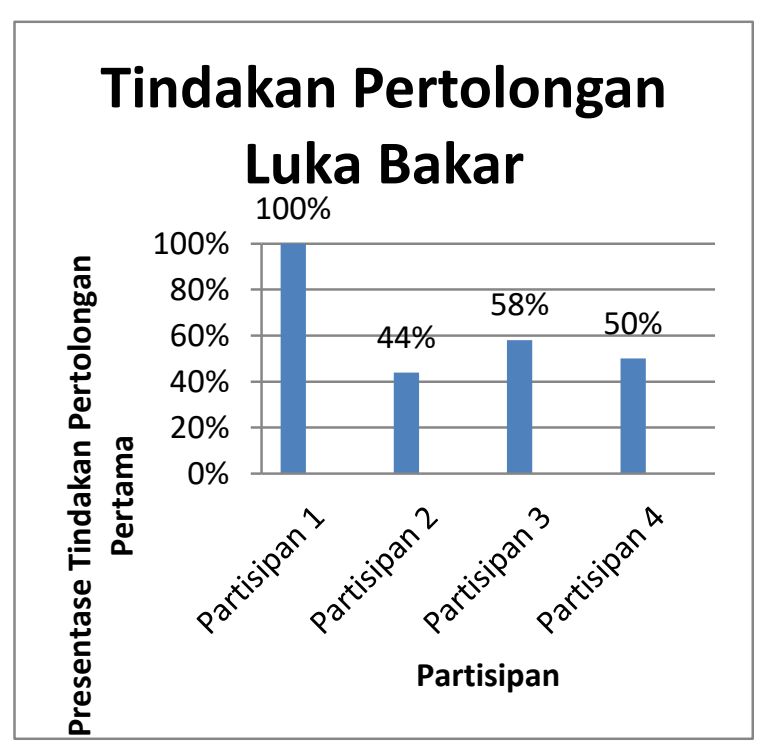

Grafik 1. Persentase Kemampuan Partisipan dalam memberikan Pertolongan Pertama Luka Bakar

Berdasarkan grafik 1 menunjukkan bahwa kemampuan partisipan 1 dalam melakukan pertolongan pertama pada luka bakar sesuai SOP adalah $100 \%$, partisipan 2 kemampuan melakukan pertolongan pertama pada luka bakar sesuai SOP adalah 44\%, partisipan 3 kemampuan melakukan pertolongan pertama pada luka bakar sesuai SOP adalah 58\% dan partisipan 4 kemampuan dalam melakukan pertolongan pertama pada luka bakar sesuai SOP adalah 50\%.

Berdasarkan hasil penelitian dengan melakukan wawancara maka masing-masing langkah pertolongan pertama pada luka bakar yang dilakukan oleh masing-masing partisipan adalah sebagai berikut: 


\section{Partisipan 1 (Ny. A)}

Partisipan 1 melakukan pertolongan pertama pada luka bakar ringan yang ditandai dengan warna kemerahan, nyeri, dan bengkak, yang disebabkan oleh panas setrika yang mengenai tangan kiri bagian dalam, luas luka bakar 2,25\%. Dari 8 langkah SOP pertolongan luka bakar ringan didapatkan partisipan melakukan semua dengan benar, maka kemampuan dalam memberikan pertolongan pertama mendapatkan nilai $100 \%$, dengan langkah-langkah pertolongan pertama yang dilakukan adalah sebagai berikut:

1. Sebelum menolong memastikan aman diri, aman korban, dan aman lingkungan.

2. Tidak panik ketika menolong korban luka bakar, karena telah mendapat informasi tentang pertolongan pertama luka bakar dan pelatihan PMR.

3. Menghilangkan sumber luka bakar dengan cara mencabut kabel setrika dan menjauhkan korban dari tempat kejadian.

4. Mendinginkan luka bakar dengan air mengalir selama 5-7 menit.

5. Kemudian tidak mengolesi odol karena tahu akan menghambat penguapan suhu pada luka.

6. Menutup luka dengan kasa.

7. Membawa ke rumah sakit.

Partisipan 2 (Tn. P)
Partisipan 2 melakukan pertolongan pertama pada luka bakar sedang yang ditandai dengan warna merah/pucat, nyeri, dan terdapat bulla, yang disebabkan oleh air panas, luas luka bakar 4,5\% di sekitar dada. Dari 9 langkah SOP pertolongan pertama pada luka bakar sedang, didapatkan partisipan melakukan 4 langkah yang sesuai, maka kemampuan dalam memberikan pertolongan pertama mendapatkan nilai $44 \%$, dengan langkah-langkah pertolongan pertama yang dilakukan adalah sebagai berikut:

1. Pada saat kejadian luka bakar partisipan mengamankan korban dengan cara menjauhkan korban dari tempat kejadian.

2. Panik ketika menolong korban, karena belum pernah mendapat informasi tentang pertolongan pertama luka bakar.

3. Mengolesi luka dengan odol, dengan alasan kebiasaan di lingkungan agar luka terasa dingin.

4. Kemudian mendinginkan luka bakar dengan kipas, sampai korban dibawa ke rumah sakit.

5. Tidak memecah bula ketika mengetahui luka terdapat bulla.

6. Segera membawa ke rumah sakit dengan sepeda motor.

\section{Partisipan 3 (Tn. J)}

Partisipan 3 melakukan pertolongan pertama pada luka bakar berat yang ditandai 
dengan warna pucat/putih, dan nyeri, yang disebabkan oleh tersiram air panas, luas luka bakar 9\% di paha kanan sampai lutut. Dari 12 langkah SOP pertolongan luka bakar berat didapatkan partisipan 3 melakukan 7 langkah yang sesuai, maka kemampuan dalam memberikan pertolongan pertama mendapatkan nilai 58\%, dengan langkahlangkah pertolongan pertama yang dilakukan sebagai berikut:

1. Memastikan aman diri, aman pasien dengan cara mengangkat korban dari tempat kejadian.

2. Berteriak meminta bantuan ke anggota keluarga lain.

3. Panik ketika menolong, meskipun sudah pernah mendapat informasi tentang luka bakar.

4. Menghentikan luka bakar dengan cara menyiram dengan air pada bagian yang tersiram air panas.

5. Melepaskan pakaian yang menutupi luka korban agar pakaian tidak melekat dengan luka.

6. Mendinginkan luka bakar dengan air selama 10-15 menit, dengan cara menyiram dengan air.

7. Tidak ada pendarahan di bagian luka bakar.

8. Melindungi area luka bakar dengan kain basah ketika akan dibawa ke rumah sakit agar luka tetap dingin.
9. Segera membawa ke rumah sakit dengan mobil.

\section{Partisipan 4 (Ny. A)}

Partisipan 4 melakukan pertolongan pertama pada luka bakar berat yang ditandai dengan warna pucat/putih, dan kulit hitam/gosong, yang disebabkan oleh api, luas luka bakar $18 \%$ di bokong dan paha kanan. Dari 12 langkah SOP pertolongan luka bakar berat didapatkan partisipan melakukan 6 langkah yang sesuai, maka kemampuan memberikan pertolongan pertama mendapatkan nilai 50\%, dengan langkahlangkah pertolongan sebagai berikut:

1. Memastikan aman korban dan aman lingkungan ketika menolong, dengan cara mematikan sumber api dengan air.

2. Panik ketika menolong, karena tidak pernah menolong kejadian luka bakar.

3. Menghentikan luka bakar dengan menggunakan handuk basah yang ditaruh di bagian tubuh yang terkena api.

4. Memanggil nama korban karena korban tidak sadar, dan mengecek pernafasan dengan melihat dada korban.

5. Berteriak meminta pertolongan ke orang yang berada disekitar rumah.

6. Ketika bantuan datang partisipan memindahkan korban ke tempat yang aman dan membebaskan dari benda-benda yang terbakar dengan cara menggunting pakaian. 
7. Mendinginkan luka bakar dengan kipas sambil menunggu dibawa ke rumah sakit.

8. Tidak ada pendarahan di bagian luka bakar, hanya kulit berwarna hitam.

9. Membawa ke rumah sakit.

\section{Pembahasan}

\section{Luka Bakar Ringan (Partisipan 1)}

Partisipan 1 menunjukkan tindakan yang dilakukan sesuai SOP. Berdasarkan hasil wawancara partisipan 1 pernah mendapat informasi tentang pertolongan pertama luka bakar dan mendapat pelatihan pertolongan pertama saat mengikuti PMR. Hal ini yang mendasari langkah-langkah yang dilakukan partisipan 1 sesuai dengan SOP pertolongan pertama luka bakar. Menurut Anggraini dkk (2018), SOP atau standar operasional prosedur merupakan acuan atau dapat dikatakan pedoman baku dalam melaksanakan suatu aktivitas tertentu. Suatu unit kerja tertentu dapat dikatakan berhasil dan bekerja secara benar apabila semua aktivitas pekerjaannya mengacu pada SOP bidangnya. Tujuan utama dari SOP adalah untuk mempermudah setiap proses kerja dan meminimalisir adanya kesalahan dalam proses pengerjaanya.

Berdasarkan wawancara dan observasi keterampilan pada partisipan 1 menunjukan kesesuaian langkah-langkah dalam melakukan pertolongan pertama luka bakar karena informasi yang pernah didapat partisipan 1 tentang cara pertolongan pertama luka bakar dan pengalaman yang didapat dari pelatihan pertolongan pertama pada saat mengikuti PMR.

\section{Luka Bakar Sedang (Partisipan 2)}

Partisipan 2 melakukan tindakan tidak urut sesuai SOP dan beberapa tindakan yang salah. Partisipan 2 panik ketika menolong korban karena belum pernah mendapat informasi tentang pertolongan pertama luka bakar. Menurut Pieter (2011), panik adalah lapangan persepsi yang sangat sempit sekali dan tidak mampu berpikir logis. Adapun respons perilaku dan emosinya terlihat agitasi, mengamuk dan marah-marah, ketakutan, berteriak-teriak, blocking, kehilangan kontrol diri, dan memiliki persepsi yang kacau.

Partisipan 2 langsung mengolesi luka dengan odol, dengan alasan kebiasaan di lingkungan agar luka terasa dingin. Menurut Yulianingsih (2017) dalam SOP pertolongan pertama luka bakar, mengolesi luka bakar dengan odol, mentega, minyak, kecap atau yang lainnya akan memperparah keadaan luka yang ada, cara ini akan memperparah keadaan luka karena bahan tersebut akan menutup pori-pori kulit sehingga kulit yang terbakar akan sulit untuk dibersihkan dan akan menghambat penguapan suhu pada luka. 
Partisipan 2 tidak membebaskan pakaian pada bagian luka, hal ini yang mengakibatkan baju melekat dengan luka korban. Menurut SOP pertolongan pertama luka bakar, segera membebaskan benda-benda yang mudah meleleh/terbakar di sekitar area luka yang terbakar untuk menghindari pakaian menempel pada luka, dan mengurangi keparahan luka bakar (Yulianingsih, 2017).

Berdasarkan hasil wawancara dan observasi keterampilan pada partisipan 2 diketahui partisipan 2 melakukan tindakan tidak sesuai SOP, dikarenakan partisipan tidak pernah mendapat informasi tentang pertolongan pertama luka bakar dan masih mempercayai mitos di masyarakat tentang pertolongan pertama luka bakar dengan menggunakan odol.

\section{Luka Bakar Berat (Partisipan 3 dan Partisipan 4)}

Partisipan 3 dan partisipan 4 menunjukkan tindakan yang dilakukan tidak sesuai dengan SOP. Berdasarkan hasil wawancara partisipan 3 dan partisipan 4 pernah mendapat informasi tentang pertolongan pertama luka bakar. Namun beberapa tindakan yang dilakukan partisipan 3 dan partisipan 4 tidak sesuai dengan SOP. Partisipan 3 dalam memberikan pertolongan tindakan yang dilakukan pertama kali adalah memastikan aman diri, aman pasien dengan cara mengangkat korban dari tempat kejadian, sedangkan partisipan 4 mengatakan memastikan aman korban dan aman lingkungan ketika menolong dengan cara mematikan sumber api. Hal ini tidak sesuai dengan SOP pertolongan pertama yang selalu mengutamakan 3A sebelum melakukan tindakan pertolongan pertama. 3A (aman diri: yaitu seorang penolong/perawat memakai alat pelindung diri/APD, aman pasien: yaitu melihat keadaan pasien apakah ada indikasi cedera, aman lingkungan: yaitu mengamankan pasien dan diri kita dari lingkungan sekitar yang membahayakan).

Partisipan 4 mendinginkan luka bakar dengan kipas sambil menunggu dibawa ke rumah sakit. Menurut SOP pertolongan pertama luka bakar cara mendinginkan luka bakar dengan cara menyiram dengan air mengalir. Menurut Stiles et al (2018) jika air tersedia, lakukan pendinginan dengan cara menyiram luka dengan air mengalir. Apabila persediaan air terbatas, maka kompres air dingin menggunakan kain bersih bebas serat. Jika tidak ada air, gunakan es atau air es untuk mendinginkan luka bakar.

Partisipan 4 tidak melindungi area luka bakar ketika dibawa ke rumah sakit. Menurut SOP pertolongan pertama luka bakar yang benar, luka harus ditutup dengan kasa/kain bersih. Menurut Yulianingsih (2017) tutup 
dengan kasa steril dan plester untuk mencegah gesekan antara luka dengan pakaian yang dikenakan, juga untuk melindungi luka dari debu.

Berdasarkan hasil wawancara dan observasi keterampilan pada partisipan 3 dan partisipan 4, diketahui pada partisipan 3 masih panik meskipun sudah mendapat informasi tentang pertolongan pertama pada korban luka bakar, namun tindakan yang dilakukan partisipan 3 sudah sesuai namun tidak urut. Pada partisipan 4 sudah mendapat informasi tentang pertolongan pertama luka bakar tetapi beberapa tindakan tidak sesuai dengan SOP, antara lain belum memastikan 3A, masih panik ketika akan menolong korban, dan mendinginkan luka menggunakan kipas, serta tidak menutup luka.

\section{Kesimpulan Dan Saran}

Berdasarkan hasil pemaparan studi kasus dapat disimpulkan bahwa tindakan pertolongan pertama yang dilakukan berbeda, tergantung jenis luka bakar, tingkat pengetahuan, pengalaman, informasi yang didapat tentang pertolongan pertama luka bakar.

Pertolongan pertama luka bakar ringan berdasarkan observasi keterampilan mendapatkan nilai $100 \%$, dengan langkahlangkah: sebelum menolong memastikan aman diri, aman korban, dan aman lingkungan, penolong tidak panik, menghilangkan sumber luka bakar dengan cara mencabut kabel setrika dan menjauhkan korban dari tempat kejadian, mendinginkan luka bakar dengan air mengalir selama 5-7 menit, tidak mengolesi odol, menutup luka dengan kasa, membawa ke rumah sakit.

Pertolongan pertama luka bakar sedang berdasarkan observasi keterampilan mendapatkan nilai 44\%, dengan langkahlangkah: mengamankan korban dengan cara menjauhkan korban dari tempat kejadian, penolong panik ketika menolong korban, mengolesi luka dengan odol, mendinginkan luka bakar dengan kipas, tidak memecah bula, segera membawa ke rumah sakit.

Pertolongan pertama luka bakar berat berdasarkan observasi keterampilan mendapatkan nilai $54 \%$, dengan langkahlangkah: memastikan aman diri dan aman pasien, berteriak meminta bantuan, penolong panik ketika menolong, menghentikan luka bakar dengan cara menyiram dengan air/menghentikan luka bakar dengan menggunakan handuk basah, memanggil nama korban karena korban tidak sadar dan mengecek pernafasan dengan melihat dada korban, melepaskan pakaian yang menutupi luka korban, mendinginkan luka bakar dengan kipas, melindungi area luka bakar dengan kain basah, segera membawa ke rumah sakit. 
Maka saran yang dapat diajukan sebagai berikut:

1. Bagi Instansi Pendidikan Kesehatan, dapat digunakan sebagai dasar untuk memberikan pendidikan kesehatan terhadap masyarakat khususnya pertolongan pertama.

2. Bagi Tempat Penelitian, dapat digunakan sebagai dasar untuk memberikan informasi pendidikan kesehatan pertolongan pertama luka bakar yang baik dan benar.

3. Bagi Peneliti Selanjutnya, dapat menjadi referensi dan sebagai bahan untuk peneliti selanjutnya melakukan penelitian tentang pemberian pendidikan kesehatan pertolongan pertama yang baik dan benar di masyarakat, dan sebaiknya tidak hanya di Wilayah Kerja Puskesmas Selopuro tetapi di seluruh Kabupaten Blitar.

\section{Referensi}

Anggraini, dkk. 2018. Pendidikan Kesehatan Pertolongan Pertama pada Kecelakaan pada Masyarakat di Kelurahan Dandangan. Journal of Community Engagement in Health. 1(2), 21-24. Diperoleh dari https://www.jceh.org/index.php/JCEH/a rticle/view/10/16

Arikunto, S. 2010. Prosedur Penelitian: Suatu Pendekatan Praktik. Jakarta: Rineka Cipta

Badan Penelitian \& Pengembangan Kesehatan Kemenkes RI. 2019. Laporan Nasional Riset Kesehatan Dasar 2018. Jakarta: Badan Penelitian \& Pengembangan Kesehatan. Diperoleh dari https://labmandat.litbang.kemkes.go.id/i mages/download/laporan/RKD/2018/La poran_Nasional_RKD2018_FINAL.pd

Herawati, L, \& Argarini, R. 2015. Penanganan Pertama Luka Pada Anak. Sidoarjo: Oksana Publishing.

Noer, dkk. 2018. Emergency Management of Major Burn. Surabaya: PT Revka Petra Media

Pieter, Herri Zan. 2011. Pengantar Psikopatologi Untuk Keperawatan. Jakarta: Kencana

Susilowati, R. 2015. Jurus Rahasia Menguasai P3K: Pertolongan Pertama Pada Kecelakaan. Lembar langit Indonesia.

Sutomo, dkk. 2008.Tenik Menyusun KTISKRIPSI-TULISAN ILMIAH dalam Jurnal Bidang Kebidanan, Keperawatan dan Kesehatan. Yogyakarta: F Tramaya

Stiles, Kristina \& Goodwin, N (2018, April ). Retrieved August 21, 2018, from https://www.britishburnassociation.org/ wp-content/uploads/2017/06/BBAFirst-Aid-Guideline-24.7.18.pdf

Yulianingsih, Nengah. 2017. Self Help Emergency: Panduan Pertolongan Pertama pada Kecelakaan Sehari-hari. Yogyakarta: Andi 